J. Dairy Sci. 95:2319-2325

http://dx.doi.org/10.3168/jds.2011-5066

(C) American Dairy Science Association ${ }^{\circledR}, 2012$.

\title{
Effects of cooling and freezing storage on the stability of bioactive factors in human colostrum
}

\author{
C. Ramírez-Santana, ${ }^{\star} \dagger$ F. J. Pérez-Cano, ${ }^{\star}$ C. Audí, ${ }^{\star}$ M. Castell, ${ }^{\star}$ M. G. Moretones,‡ M. C. López-Sabater, †§ \\ C. Castellote, ${ }^{*} \dagger$ and A. Franch ${ }^{\star} \dagger^{1}$ \\ ${ }^{*}$ Department of Physiology, Faculty of Pharmacy, University of Barcelona, Av. Joan XXIII s/n, 08028 Barcelona, Spain \\ †CIBER Epidemiología y Salud Pública (CIBERESP), C/ Dr. Aiguader, 88, 1a planta, 08003 Barcelona, Spain \\ ¥Servei de Neonatologia, ICGON, Agrupació Sanitària Hospital Clínic-Hospital Sant Joan de Déu, Universitat de Barcelona, \\ C. Sabino Arana, 1, 08028 Barcelona, Spain \\ §Department of Nutrition and Food Sciences, Faculty of Pharmacy, University of Barcelona, Av. Joan XXIII s/n, 08028 Barcelona, Spain
}

\begin{abstract}
Breast milk constitutes the best form of newborn alimentation because of its nutritional and immunological properties. Banked human milk is stored at low temperature, which may produce losses of some bioactive milk components. During lactation, colostrum provides the requirements of the newborn during the first days of life. The aim of this study was to evaluate the effect of cooling storage at $4^{\circ} \mathrm{C}$ and freezing storage at $-20^{\circ} \mathrm{C}$ and $-80^{\circ} \mathrm{C}$ on bioactive factors in human colostrum. For this purpose, the content of $\operatorname{IgA}$, growth factors such as epidermal growth factor, transforming growth factor (TGF)- $\beta 1$ and TGF- $\beta 2$, and some cytokines such as IL-6, IL-8, IL-10, and tumor necrosis factor (TNF)- $\alpha$, and its type I receptor TNF-RI, were quantified. Some colostrum samples were stored for 6,12 , 24 , and $48 \mathrm{~h}$ at $4^{\circ} \mathrm{C}$ and others were frozen at $-20^{\circ} \mathrm{C}$ or $-80^{\circ} \mathrm{C}$ for 6 and 12 mo. We quantified $\operatorname{IgA}$, epidermal growth factor, TGF- $\beta 1$, and TGF- $\beta 2$ by indirect ELISA. Concentrations of IL-6, IL-10, and TNF- $\alpha$ cytokines, IL-8 chemokine, and TNF-RI were measured using the BD Cytometric Bead Array (BD Biosciences, Erembodegem, Belgium). Bioactive immunological factors measured in this study were retained in colostrum after cooling storage at $4^{\circ} \mathrm{C}$ for at least $48 \mathrm{~h}$, with the exception of IL-10. None of the initial bioactive factor concentrations was modified after 6 mo of freezing storage at either $-20^{\circ} \mathrm{C}$ or $-80^{\circ} \mathrm{C}$. However, freezing storage of colostrum at $-20^{\circ} \mathrm{C}$ and $-80^{\circ} \mathrm{C}$ for $12 \mathrm{mo}$ produced a decrease in the concentrations of IgA, IL-8, and TGF- $\beta 1$. In summary, colostrum can be stored at $4^{\circ} \mathrm{C}$ for up to $48 \mathrm{~h}$ or at $-20^{\circ} \mathrm{C}$ or $-80^{\circ} \mathrm{C}$ for at least 6 mo without losing its immunological properties. Future studies are necessary to develop quality assurance guidelines for the storage of colostrum in human milk
\end{abstract}

Received October 20, 2011.

Accepted January 9, 2012.

${ }^{1}$ Corresponding author: angelsfranch@ub.edu banks, and to focus not only on the microbiological safety but also on the maintenance of the immunological properties of colostrum.

Key words: human colostrum, human milk bank, immunoglobulin A, cooling and freezing storage

\section{INTRODUCTION}

Human milk constitutes the best form of newborn alimentation because of its nutritional and immunological properties. Maternal milk consists of proteins, lipids, carbohydrates, and mineral and vitamin elements in adequate quality and quantity for the development of the newborn (Picciano, 2001; Lawrence and Pane, 2007). Furthermore, human milk contains a complex mixture of immunologically active components providing both specific and nonspecific defenses against infectious agents. The main specific defense is represented by high levels of IgA, which confers passive immune protection to the neonate (Adkins et al., 2004). Other bioactive substances present in breast milk with immunomodulatory potential include a variety of growth factors and cytokines (Bryan et al., 1999). Among them are proinflammatory cytokines, such as IL-6, IL-8, and tumor necrosis factor (TNF)- $\alpha$; immunoregulatory cytokines such as IL-10; and epidermal growth factor (EGF) and transforming growth factors (TGF)- $\beta 1$ and TGF- $\beta 2$ involved in the promotion of neonatal immune development (Playford et al., 2000; Oddy et al., 2003; Walker, 2010). The list of bioactive compounds also includes IL-1, IL-3, IL-4, IL-5, IL-12, IFN- $\gamma$, and TNFreceptor I (TNF-RI; Lawrence and Pane, 2007). However, milk composition changes over the 3 human lactation periods: the well-defined colostrum, transitional milk, and mature milk. In the first days postpartum, the residual prepartum milk present in the mammary gland and ducts at delivery is progressively mixed with newly secreted milk, forming colostrum, which provides the nutritional requirements of the newborn during the first week of life (Oslislo et al., 2007). Colostrum is 
rich in proteins, minerals, and immunological factors and, among other effects, it facilitates growth of Lactobacillus bifidus in the gastrointestinal tract due to the prebiotic effects of its oligosaccharides (Araújo et al., 2005). Colostrum has the highest concentrations of $\operatorname{IgA}$, cytokines, soluble receptors of these cytokines, and growth factors at a time when neonatal organ systems are immature (Chantry et al., 2009; Castellote et al., 2011), highlighting the importance of this early milk in the future development of neonatal immune defenses. Undoubtedly, breast milk is the optimal source of indispensable antimicrobial growth factors and defensive agents. For sick and preterm newborn infants who cannot be breastfed from their own mother's milk (Wight, 2001), donor breast milk can be supplied by human milk-banking associations (Larson et al., 1984; Ogundele, 2000). Clinically, the use of donor human milk has been shown to prevent necrotizing enterocolitis, reduce feeding intolerance, and improve long-term outcomes in premature infants (Arslanoglu et al., 2010). The donated milk is often stored for varying periods (cooled, frozen, or cooled and then frozen) and pasteurized to ensure its microbial safety before being ready to use. Literature concerning the stability of bioactive factors during milk storage is very limited and therefore the choice of the most appropriate storage method and the period for which the milk can be stored safely is not often easy to establish.

The aim of this study was to evaluate the effect of 2 ways of human colostrum storage: cooling at $4^{\circ} \mathrm{C}$ for a short period $(6,12,24$, and $48 \mathrm{~h})$, and freezing at $-20^{\circ} \mathrm{C}$ or $-80^{\circ} \mathrm{C}$ for periods of 6 and 12 mo. The loss of some bioactive immunological components such as $\operatorname{IgA}$, growth factors such as EGF, TGF- $\beta 1$, and TGF- $\beta 2$, and some cytokines such as IL-6, IL-8, IL-10, and TNF- $\alpha$ and its type I receptor TNF-RI, in human colostrum were evaluated after these different storing processes and periods.

\section{MATERIALS AND METHODS}

\section{Milk Samples}

Human milk samples were collected at $3 \pm 1 \mathrm{~d}$ postpartum (i.e., colostrum) from mothers delivering at term, between wk 38 and 42 of physiological gestation, at the Clinic-Maternity Hospital of the University of Barcelona, Spain. Informed consent to participate was obtained from each mother after she had received information about the aim and design of the study. The study protocol was approved by the Hospital Ethical Committee for Human Research. The exclusion criteria for mothers were diabetes or gestational diabetes, eclampsia, immunodeficiency, malnutrition, recent local or systemic infectious diseases, psychiatric disorders, and drug addiction.

Colostrum was collected using an electric breast pump (Ameda, Lactaline, Zug, Switzerland) during hospitalization. Colostrum samples were collected in aseptic flasks between 0800 and $1200 \mathrm{~h}$ by the complete emptying of both breasts. All samples were maintained at $4^{\circ} \mathrm{C}$ and aliquoted within $2 \mathrm{~h}$ after collection.

\section{Cooling Storage}

Ten colostrum samples from 10 individual mothers were divided into 5 aliquots each and stored for 0,6 , 12,24 , or $48 \mathrm{~h}$ at $4^{\circ} \mathrm{C}$, with each time span constituting the cooling storage groups. After cooling storage, milk whey was separated as described previously (Permanyer et al., 2010). Briefly, the milk fatty layer and cellular elements were removed by centrifugation at 800 $\times g$ for 10 min at $4^{\circ} \mathrm{C}$. The intermediate aqueous phase was aliquoted to avoid repeated freeze-thaw cycles and stored at $-80^{\circ} \mathrm{C}$ for up to $1 \mathrm{wk}$ before analyzing the concentration of bioactive factors. The reference group (0 h of cooling storage, time 0 ) consisted of milk whey from freshly extracted colostrum, which was immediately stored at $-80^{\circ} \mathrm{C}$ and analyzed with the other sample groups.

\section{Freezing Storage}

To study freezing storage, each sample $(\mathrm{n}=10)$ was obtained by pooling the colostrum from 2 or 3 donor mothers. Each sample was divided into 5 aliquots, corresponding to the different storage conditions. The reference group consisted of milk whey from 1 aliquot of each pooled sample, frozen at $-80^{\circ} \mathrm{C}$, and analyzed after a maximum of 1 wk. Two aliquots were stored at $-20^{\circ} \mathrm{C}$ and 2 at $-80^{\circ} \mathrm{C}$, both for 6 or 12 mo. After freezing storage, milk whey was separated as described above, frozen at $-80^{\circ} \mathrm{C}$, and analyzed within the next week.

\section{Quantification of IgA, EGF, TGF- $\beta 1$, and TGF- $\beta 2$}

Immunoglobulin A was measured in colostrum whey using an ELISA quantitation kit from Bethyl Laboratories (Montgomery, TX) at dilutions of more than 1:10,000. Epidermal growth factor was quantified using a Human EGF DuoSet (R\&D Systems, Minneapolis, $\mathrm{MN})$, with a minimum detectable concentration of 3.9 $\mathrm{pg} / \mathrm{mL}$. Transforming growth factor- $\beta 1$ and TGF- $\beta 2$ were measured using a Human TGF- $\beta 1$ and TGF- $\beta 2$ DuoSet (R\&D Systems), and the minimum detectable concentration for both ELISA was $31.25 \mathrm{pg} / \mathrm{mL}$. A standard acidification and neutralization procedure 
was used for conversion of TGF- $\beta 1$ and TGF- $\beta 2$ to the active form.

\section{Quantification of IL-6, IL-8, IL-10, TNF- $\alpha$, and TNF-RI}

Concentrations of IL-6, IL-10, and TNF- $\alpha$ cytokines, IL-8 chemokine, and TNF-RI were measured using the BD Cytometric Bead Array Human Soluble Protein Flex Set (BD Biosciences, Erembodegem, Belgium). Briefly, samples or standards with a mix of specific fluorescent beads for each analyte were incubated for 1 $\mathrm{h}$ at 20 to $25^{\circ} \mathrm{C}$ in the dark. Later, a mix with the detection antibodies conjugated with phycoerythrin was added and incubated for $2 \mathrm{~h}$ under the same conditions. Samples were washed by centrifugation at $200 \times g$ for 5 min and analyzed using a BD FACSAria cytometer (BD Biosciences) and the FCAP Array Software (BD Biosciences). All 5 determinations consumed as little as $50 \mu \mathrm{L}$ of diluted milk whey. The minimum detectable concentration was $1.6 \mathrm{pg} / \mathrm{mL}$ for IL- $6,1.2 \mathrm{pg} / \mathrm{mL}$ for IL-8, $0.13 \mathrm{pg} / \mathrm{mL}$ for IL- $10,0.7 \mathrm{pg} / \mathrm{mL}$ for TNF- $\alpha$, and $5.2 \mathrm{pg} / \mathrm{mL}$ for TNF-RI.

\section{Statistical Analysis}

Because antibody and cytokine concentrations are not normally distributed (Filteau, 2009), a nonparametric test was used. For both types of storage, cooling and freezing, the Friedman test for paired samples was carried out, and when storage treatment had a significant effect on the concentration of the bioactive factors, a post hoc pairwise comparison test was performed. The PASW Statistics 18 software package (SPSS Inc., Chicago, IL) was used for the statistical analyses. Differences were considered significant at $P$-values $<0.05$. All data are expressed as the mean \pm standard error of the mean.

\section{RESULTS AND DISCUSSION}

Neonatal immune development is based on bioactive immunological factors in milk. Thus, it is important to know whether current storage methodologies used in hospital neonatal care units or in human milk banks are appropriate for preserving these compounds and therefore for maintaining the immunological properties ascribed to breast milk.

Because human milk banks and neonatal intensive care units have increased their activities in recent years, it seems necessary to establish guidelines for milk collection, processing, and quality control. In light of this, rather than just ensuring the microbiological safety of stored milk, an urgent need exists to define standardized conditions to preserve the nutritional and immu- nological constituents of stored milk. In this sense, the stability of some nutrients with special interest for the neonate, such as vitamins and lipids, has been studied after human milk refrigeration and freezing storage. Overall, lipids (triglycerides and fatty acids) and some vitamins remain stable for at least $48 \mathrm{~h}$ at $4^{\circ} \mathrm{C}$ and for up to $6 \mathrm{mo}$ at $-20^{\circ} \mathrm{C}$ or $-80^{\circ} \mathrm{C}$ (Romeu-Nadal et al., 2008; Tacken et al., 2009).

This study describes the effect of cooling at $4^{\circ} \mathrm{C}$ and freezing at $-20^{\circ} \mathrm{C}$ and $-80^{\circ} \mathrm{C}$ on the content of bioactive factors in human colostrum during short- and long-term storage, respectively. The immunoactive factors studied were distributed, according to their relative colostrum concentration, into 3 groups: the main immunological component, $\operatorname{IgA}(\mathrm{mg} / \mathrm{mL})$; the major factors $(\mathrm{ng} / \mathrm{mL})$, which include EGF, IL-8, TGF- $\beta 2$, TGF- $\beta 1$, and TNF-RI; and the minor factors $(\mathrm{pg} / \mathrm{mL})$, such as TNF- $\alpha$, IL-6, and IL-10.

\section{Cooling and Freezing Storage on the Main Colostrum Antibody: IgA}

Immunoglobulin A is probably the most studied immunological component in human milk because it is the dominant Ig in human milk (Goldman, 2007). Colostral $\operatorname{IgA}$ is preferentially transferred to the neonate during the first $3 \mathrm{~d}$ postpartum, and approximately $4 \mathrm{~g}$ of $\operatorname{IgA}$ is ingested by the newborn during the first day of breastfeeding. This high amount of ingested IgA is similar to the daily production of mucosal $\operatorname{IgA}$ in a normal adult and provides passive protection at the infant's mucosal surfaces (Mestecky and McGhee, 1987; Uruakpa et al., 2002). In this study, the IgA concentration remained similar at $4^{\circ} \mathrm{C}$ within the 48 -h period after obtaining the colostrum (Table 1). These results are in line with those found in mature milk up to $24 \mathrm{~h}$ by Hines et al. (2007) and with those of Slutzah et al. (2010) in milk stored up to $96 \mathrm{~h}$, the latter also finding no changes in lactoferrin, total fat, or total gram-negative colony counts. Regarding the freezing stability of IgA, previous studies have reported that storing mature milk samples at $-20^{\circ} \mathrm{C}$ for 1 wk and 1 mo (Evans et al., 1978) or 3 mo (Reynolds et al., 1982) has no effect on the contents of $\operatorname{IgA}, \operatorname{IgG}$, and IgM. In contrast, Akinbi et al. (2010) found $50 \%$ loss of IgA after 4 wk at $-20^{\circ} \mathrm{C}$. In line with former results, our results showed that the initial IgA concentration in colostrum was not modified after 6 mo of storage at $-20^{\circ} \mathrm{C}$ or $-80^{\circ} \mathrm{C}$ (Figure $1 \mathrm{~A}$ ). However, storage of the colostrum for 12 mo resulted in a decrease in the concentration of $\operatorname{IgA}$ at $-20^{\circ} \mathrm{C}$ and $-80^{\circ} \mathrm{C}(P<0.01)$. As can be seen in Figure $1 \mathrm{~A}$, the IgA loss compared with the initial concentration was approximately 41 or $36 \%$ after storage for 12 mo at $-20^{\circ} \mathrm{C}$ or $-80^{\circ} \mathrm{C}$, respectively. Using time 0 as a refer- 
Table 1. Effect of cold storage $\left(4^{\circ} \mathrm{C}\right)$ on the content of bioactive factors in human colostrum ${ }^{1}$

\begin{tabular}{|c|c|c|c|c|c|}
\hline \multirow[b]{2}{*}{ Bioactive factor $^{2}$} & \multicolumn{5}{|c|}{ Length of storage (h) } \\
\hline & 0 & 6 & 12 & 24 & 48 \\
\hline $\operatorname{IgA}(\mathrm{mg} / \mathrm{mL})$ & $8.8 \pm 1.3$ & $8.6 \pm 1.2$ & $8.2 \pm 1.3$ & $8.4 \pm 1.2$ & $8.6 \pm 1.2$ \\
\hline EGF (ng/mL) & $120 \pm 22.1$ & $128 \pm 21.7$ & $118 \pm 18.1$ & $127 \pm 21.0$ & $114 \pm 22.4$ \\
\hline IL-8 (ng/mL) & $5.4 \pm 1.4$ & $5.3 \pm 1.5$ & $5.2 \pm 1.6$ & $4.9 \pm 1.5$ & $5.0 \pm 1.3$ \\
\hline TGF- $\beta 2(\mathrm{ng} / \mathrm{mL})$ & $5.6 \pm 1.2$ & $6.0 \pm 1.4$ & $5.6 \pm 1.2$ & $6.0 \pm 1.4$ & $5.7 \pm 1.3$ \\
\hline TGF- $\beta 1$ (ng/mL) & $1.5 \pm 0.3$ & $1.4 \pm 0.3$ & $1.4 \pm 0.3$ & $1.4 \pm 0.3$ & $1.4 \pm 0.3$ \\
\hline TNF-RI (ng/mL) & $1.4 \pm 0.2$ & $1.4 \pm 0.2$ & $1.4 \pm 0.2$ & $1.4 \pm 0.2$ & $1.5 \pm 0.3$ \\
\hline TNF- $\alpha(\mathrm{pg} / \mathrm{mL})$ & $20.9 \pm 4.9$ & $20.6 \pm 5.0$ & $19.1 \pm 4.5$ & $19.6 \pm 5.0$ & $18.9 \pm 4.8$ \\
\hline IL-6 $(\mathrm{pg} / \mathrm{mL})$ & $93.2 \pm 19.1$ & $89.2 \pm 19.3$ & $83.0 \pm 15.5$ & $84.5 \pm 17.0$ & $83.2 \pm 16.7$ \\
\hline IL-10 (pg/mL) & $11.3 \pm 3.3$ & $10.8 \pm 3.2$ & $9.7 \pm 2.9$ & $9.4 \pm 3.1$ & $8.8 \pm 2.7^{* *}$ \\
\hline
\end{tabular}

ence, the stability of $\operatorname{IgA}$ did not appear to be linear. The IgA loss after long cold storage and our previous studies using pasteurization or high-pressure processing (Permanyer et al., 2010) indicate that IgA is the milk immunological factor with the highest temperature and pressure lability. Based on these IgA data, human colostrum can be stored cooled for up to $48 \mathrm{~h}$, or frozen for a period of at least $6 \mathrm{mo}$, regardless of the type of freezing used (i.e., $-20^{\circ} \mathrm{C}$ or $-80^{\circ} \mathrm{C}$ conditions).

\section{Cooling and Freezing Storage on Major Colostrum Bioactive Factors: EGF, IL-8, TGF- $\beta 2$, TGF- $\beta 1$, and TNF-RI}

Among the major milk bioactive components, EGF is one of the main peptide growth factors present in human milk and plays an important role in the development and protection of the gastrointestinal tract in the neonate (Hirai et al., 2002; Oslislo et al., 2007). In this study, the initial EGF concentration in human colostrum was not modified either after cooling for 48 $\mathrm{h}$ (Table 1) or after freezing for $12 \mathrm{mo}$ at $-20^{\circ} \mathrm{C}$ or $-80^{\circ} \mathrm{C}$ (Figure $1 \mathrm{~A}$ ). The stability exhibited by EGF is especially relevant when stored milk is prescribed to preterm and very preterm infants due to their high need for this factor (Dvorak, 2010).

The human fetal and neonatal gastrointestinal tract is exposed to biologically significant concentrations of IL-8 swallowed with amniotic fluid and human milk, respectively (Laham et al., 1993). This indicates that, in addition to its better-known role as a neutrophil chemoattractant, IL-8 has a trophic function in the developing human intestine (Maheshwari et al., 2002). The content of IL-8 in the reference colostrum samples did not change after being stored at $4^{\circ} \mathrm{C}$ for up to 48 h (Table 1) or at $-20^{\circ} \mathrm{C}$ or $-80^{\circ} \mathrm{C}$ for 6 mo (Figure
1A). However, colostrum stored for $12 \mathrm{mo}$ at $-20^{\circ} \mathrm{C}$ and $-80^{\circ} \mathrm{C}$ showed significant losses of IL- 8 content of about $33 \%$ and $25 \%$, respectively (Figure $1 \mathrm{~A}$ ). Our recently reported data confirm the importance of IL-8 in infant growth. We have found a negative correlation between milk IL-8 content and birth weight: the earlier the delivery (very premature infants), the higher the IL-8 milk concentration (Castellote et al., 2011).

Transforming growth factor- $\beta 1$ and TGF- $\beta 2$ isoforms constitute key immunoregulatory factors for the establishment of the mucosal immune response by promoting IgA production as well as induction of oral tolerance (Strobel, 2002; Ogawa et al., 2004). In colostrum samples, the initial TGF- $\beta 2$ content was 2 - to 4 -fold higher than that of TGF- $\beta 1$. The concentration of both TGF- $\beta$ isoforms present in human colostrum remained similar throughout cooling storage, maintaining their relative proportion for up to $48 \mathrm{~h}$ (Table 1 ). With regard to freezing storage, although the concentration of TGF- $\beta 2$ was not modified either by the length or the temperature of storage, TGF- $\beta 1$ concentration decreased after $12 \mathrm{mo}$ of storage at $-20^{\circ} \mathrm{C}$ and $-80^{\circ} \mathrm{C}$, with losses of approximately 13 and $11 \%$, respectively $(P<0.05$; Figure 1B). Considering the high quantities of TGF- $\beta$ isoforms in human milk, the observed reductions in TGF- $\beta 1$ would not affect the immunomodulatory and tolerogenic activity of colostrum.

Previous studies have suggested that TNF-RI binding and sequestering of TNF- $\alpha$ might contribute to milk's antiinflammatory properties (Buescher and McWilliams-Koeppen, 1998). In our work, we found that colostrum TNF-RI concentration was not affected by cooling storage up to $48 \mathrm{~h}$ (Table 1) or by freezing storage up to $12 \mathrm{mo}$ at $-20^{\circ} \mathrm{C}$ or $-80^{\circ} \mathrm{C}$ (Figure $1 \mathrm{~B}$ ). Thus, TNF- $\alpha$ proinflammatory action remained counteracted by TNF-RI binding. 


\section{Cooling and Freezing Storage on Minority Colostrum Immunological Factors: TNF- $\alpha$, IL-6, and IL-10}

As TNF- $\alpha$ production is defective in the neonate (English et al., 1988), relatively high concentrations of TNF- $\alpha$ are likely to be found in early milk secretions compared with mature milk, to ensure both its defensive action against trauma and infection and its regulatory action on mammary gland development (Rudloff et al., 1992; Garofalo, 2010). The concentration of TNF- $\alpha$ was similar throughout the $48 \mathrm{~h}$ of the cooling treatment (Table 1) and was not significantly modified by length (6 or $12 \mathrm{mo}$ ) or temperature $\left(-20^{\circ} \mathrm{C}\right.$ or $-80^{\circ} \mathrm{C}$ ) of freezing storage (Figure 1C).

Interleukin-6 and IL-10 can induce IgA class switching in combination with TGF- $\beta$ (Cerutti, 2008). These cytokines present in human milk play a part in regulating mucosal defenses and limiting inflammatory reactions in the upper parts of the alimentary and respiratory tracts. Keeping human colostrum at $4^{\circ} \mathrm{C}$ for $48 \mathrm{~h}$ induced a nonsignificant loss $(\sim 10 \%)$ of IL-6 content (Table 1). With regard to colostrum freezing, we observed that IL-6 concentration was not significantly affected by storage at $-20^{\circ} \mathrm{C}$ or $-80^{\circ} \mathrm{C}$ up to $12 \mathrm{mo}$ (Figure 1C). Our IL-6 results are in line with those of Hines et al. (2007), who reported no changes of IL-6 concentration in mature human milk after being frozen at $-20^{\circ} \mathrm{C}$, although that study did not indicate the length of the freezing period.

We found evidence of IL-10 lability in this study because IL-10 was the only immunological factor affected by colostrum storage at $4^{\circ} \mathrm{C}$ (Table 1 ); we observed a $23 \%$ loss in concentration of IL-10 after $48 \mathrm{~h}$ of cooling storage $(P<0.01)$. The IL-10 loss observed in the cooling stability studies is in line with the reduction of IL-10 also observed after freezing storage (Figure 1C). The concentration of IL-10 in colostrum did not differ from the initial concentration after a 6 -mo freezing period at $-20^{\circ} \mathrm{C}$ and $-80^{\circ} \mathrm{C}$ but was significantly reduced after $12 \mathrm{mo}$ of storage at $-20^{\circ} \mathrm{C}$. According to these results, colostrum samples should be stored for up to $24 \mathrm{~h}$ at $4^{\circ} \mathrm{C}$, frozen for 6 mo at either $-20^{\circ} \mathrm{C}$ or $-80^{\circ} \mathrm{C}$, or frozen for $12 \mathrm{mo}$ at $-80^{\circ} \mathrm{C}$ to avoid a reduction in IL-10 concentration.

\section{CONCLUSIONS}

Most recommendations for optimal human milk storage conditions have focused on milk bacterial content, and few studies have addressed the effect of milk storage on bioactive immunological components. Moreover, all of these studies have focused on mature milk rather than colostrum. To our knowledge, this is the first study describing the effect of cooling at $4^{\circ} \mathrm{C}$ or freezing
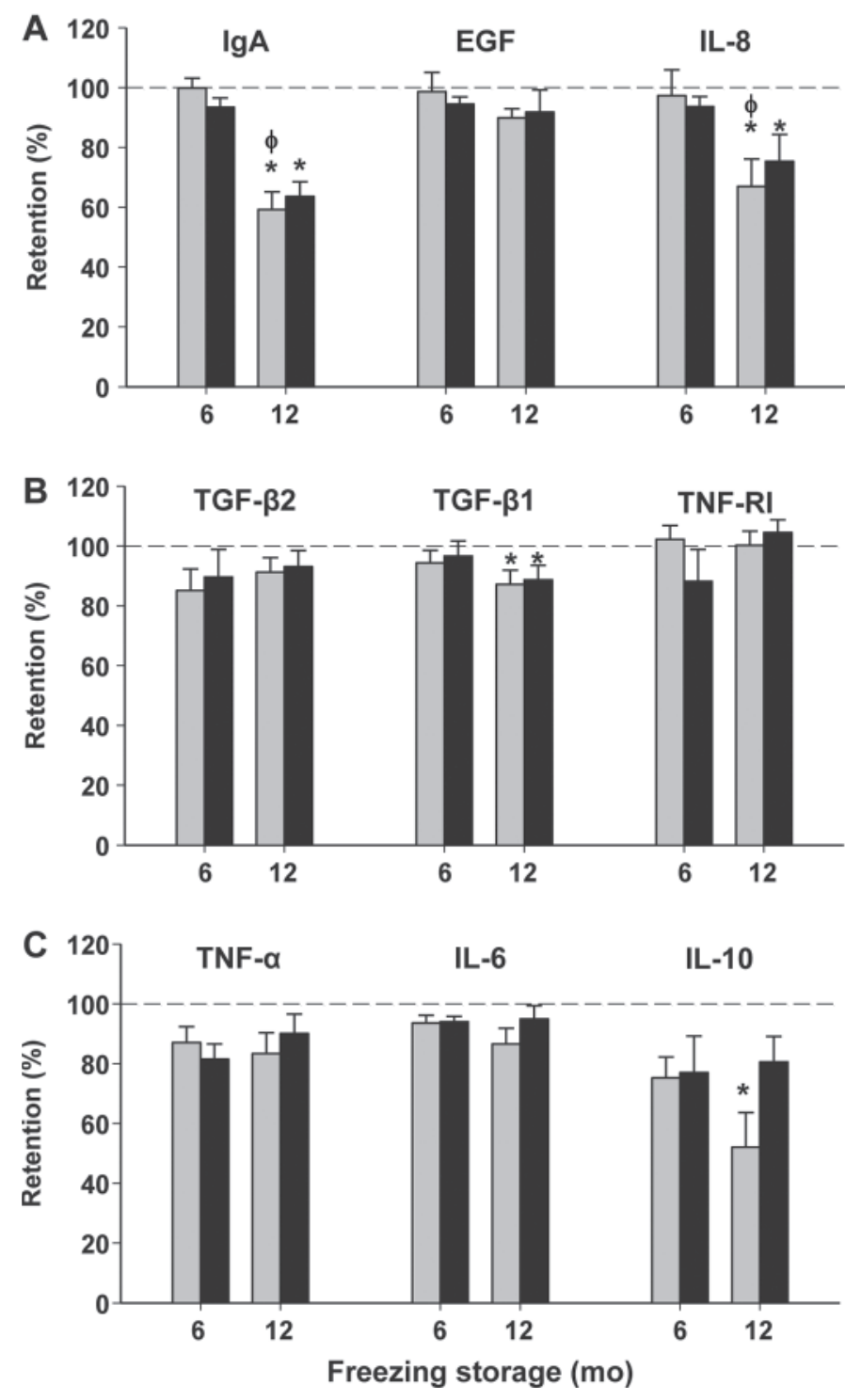

Figure 1. Percentage of bioactive factor retention in human colostrum after freezing storage at $-20^{\circ} \mathrm{C}$ and $-80^{\circ} \mathrm{C}$. (A) $\mathrm{IgA}$, epidermal growth factor (EGF), and IL-8; (B) transforming growth factor (TGF)- $\beta 2$, TGF- 31 , and tumor necrosis factor (TNF)-receptor I (TNF-RI); (C) TNF- $\alpha$, IL-6, and IL-10. Each bar represents the mean \pm SEM $(n=10)$ after 6 and 12 mo of freezing storage. Data are calculated as a percentage considering $100 \%$ the factor concentration obtained before storage for each individual sample. Storage temperature is represented by gray $\left(-20^{\circ} \mathrm{C}\right)$ and black $\left(-80^{\circ} \mathrm{C}\right)$ bars. Statistical significance: ${ }^{*} P<0.05$ vs. initial concentration; $\phi P<0.05$ vs. $6 \mathrm{mo}$, for the same storage temperature.

at $-20^{\circ} \mathrm{C}$ or $-80^{\circ} \mathrm{C}$ on the content of immune bioactive factors in human colostrum during short- and longterm storage, respectively. Taking into account only the stability of the immunological components studied, it seems reasonable to recommend cooling storage at 
$4^{\circ} \mathrm{C}$ for up to $48 \mathrm{~h}$ or freezing storage for 6 mo at either $-20^{\circ} \mathrm{C}$ or $-80^{\circ} \mathrm{C}$. Under these conditions, the contents of all the bioactive factors evaluated were maintained, except for IL-10 at $4^{\circ} \mathrm{C}$. It is remarkable that no differences were found in the concentration of bioactive factors between the 2 freezing storage temperatures assayed, indicating that $-80^{\circ} \mathrm{C}$ freezers are not required if the milk samples are not going to be stored longer than 6 mo. Milk storage at $-80^{\circ} \mathrm{C}$ up to 12 mo would reduce $\operatorname{IgA}$, IL- 8 , and TGF- $\beta 1$ contents. Understanding the effect of storage on the content of immunological components in colostrum is of great importance for human milk banks and neonatology units, because the usual recipients of human milk are preterm and other high-risk infants with a greater need than full-term infants for human colostrum compounds. Further studies are required to establish whether colostrum storage can be extended for longer than $48 \mathrm{~h}$ at $4^{\circ} \mathrm{C}$ and to identify the optimal period between 6 and 12 mo in freezing conditions that will maintain its immunoprotective and immunomodulatory capacity. Given the high concentrations of $\mathrm{IgA}$ in colostrum and mature milk, and its ease of detection, this factor could constitute the best indicator for the stability studies between 6 and 12 mo. Future studies are therefore necessary to develop highquality guidelines for storage of colostrum in human milk banks, focusing not only on its microbiological safety but also on its immunological properties.

\section{ACKNOWLEDGMENTS}

This study was funded by grants from the Spanish Ministerio de Educación y Ciencia (AGL-2005-069401/ ALI; AGL-2009-09730/ALI), from the Ministerio de Sanidad y Consumo (CIBER 06/02/0079) and from the Generalitat de Catalunya (SGCR-2005-00833). The authors are grateful to M. A. Canela (Departament de Matemàtica Aplicada i Anàlisi, Facultat de Matemàtiques, University of Barcelona, Spain) for his help with statistics and to Simon and Fliss Bage for revising the English version of the manuscript. The authors thank the Serveis Científico-Tècnics of the University of Barcelona, especially J. Comas, for expert assistance with flow cytometry. Thanks to the generosity of the parents who made this research possible.

\section{REFERENCES}

Adkins, B., C. Leclerc, and S. Marshall-Clarke. 2004. Neonatal adaptive immunity comes of age. Nat. Rev. Immunol. 4:553-564.

Akinbi, H., J. Meinzen-Derr, C. Auer, Y. Ma, D. Pullum, R. Kusano, K. J. Reszka, and K. Zimmerly. 2010. Alterations in the host defense properties of human milk following prolonged storage or pasteurization. J. Pediatr. Gastroenterol. Nutr. 51:347-352.

Araújo, E. D., A. K. Gonçalves, M. C. Cornetta, H. Cunha, M. L. Cardoso, S. S. Morais, and P. C. Giraldo. 2005. Evaluation of the secretory immunoglobulin A levels in the colostrum and milk of mothers of term and pre-term newborns. Braz. J. Infect. Dis. 9:357-362.

Arslanoglu, S., E. E. Ziegler, and G. E. Moro. 2010. Donor human milk in preterm infant feeding: Evidence and recommendations. J. Perinat. Med. 38:347-351.

Bryan, D. L., J. S. Hawkes, and R. A. Gibson. 1999. Interleukin-12 in human milk. Pediatr. Res. 45:858-859.

Buescher, E. S., and P. McWilliams-Koeppen. 1998. Soluble tumor necrosis factor- $\alpha$ (TNF- $\alpha$ ) receptors in human colostrum and milk bind to TNF- $\alpha$ and neutralize TNF- $\alpha$ bioactivity. Pediatr. Res. 44:37-42.

Castellote, C., R. Casillas, C. Ramírez-Santana, F. J. Pérez-Cano, M. Castell, M. G. Moretones, M. C. López-Sabater, and A. Franch. 2011. Premature delivery influences the immunological composition of colostrum and transitional and mature human milk. J. Nutr. 141:1181-1187.

Cerutti, A. 2008. The regulation of IgA class switching. Nat. Rev Immunol. 8:421-434.

Chantry, C. J., K. Israel-Ballard, Z. Moldoveanu, J. Peerson, A Coutsoudis, L. Sibeko, and B. Abrams. 2009. Effect of flash-heat treatment on immunoglobulins in breast milk. J. Acquir. Immune Defic. Syndr. 51:264-267.

Dvorak, B. 2010. Milk epidermal growth factor and gut protection. J. Pediatr. 156:S31-S35.

English, B. K., S. K. Burchett, J. D. English, A. J. Ammann, D. W. Wara, and C. B. Wilson. 1988. Production of lymphotoxin and tumor necrosis factor by human neonatal mononuclear cells. Pediatr. Res. 24:717-722.

Evans, T. J., H. C. Ryley, L. M. Neale, J. A. Dodge, and V. M. Lewarne. 1978. Effect of storage and heat on antimicrobial proteins in human milk. Arch. Dis. Child. 53:239-241.

Filteau, S. 2009. Measuring trace immune factors in human milk. Pages 331-337 in Breast-Feeding: Early Influence on Later Health. G. Goldberg, A. Prentice, A. Prentice, S. Filteau, and K. Simondon, ed. Advances in Experimental Medicine and Biology series, Vol. 639. Springer, London, UK.

Garofalo, R. 2010. Cytokines in human milk. J. Pediatr. 156:S36-S40.

Goldman, A. S. 2007. The immune system in human milk and the developing infant. Breastfeed. Med. 2:195-204.

Hines, E. P., J. L. Rayner, R. Barbee, A. R. Moreland, A. Valcour, J. E. Schmid, and S. E. Fenton. 2007. Assays for endogenous components of human milk: Comparison of fresh and frozen samples and corresponding analytes in serum. J. Hum. Lact. 23:144-156.

Hirai, C. H. Ichiba, M. Saito, H. Shintaku, T. Yamano, and S. Kusuda. 2002. Trophic effect of multiple growth factors in amniotic fluid or human milk on cultured human fetal small intestinal cells. J. Pediatr. Gastroenterol. Nutr. 34:524-528.

Laham, N., G. E. Rice, G. J. Bishop, C. Ransome, and S. P. Brennecke. 1993. Interleukin 8 concentrations in amniotic fluid and peripheral venous plasma during human pregnancy and parturition. Acta Endocrinol. (Copenh.) 129:220-224.

Larson, E., R. Zuill, V. Zier, and B. Berg. 1984. Storage of human breast milk. Infect. Control 5:127-130.

Lawrence, R. M., and C. A. Pane. 2007. Human breast milk: Current concepts of immunology and infectious diseases. Curr. Probl. Pediatr. Adolesc. Health Care 37:7-36.

Maheshwari, A., W. Lu, A. Lacson, A. A. Barleycorn, S. Nolan, R. D. Christensen, and D. A. Calhoun. 2002. Effects of interleukin-8 on the developing human intestine. Cytokine 20:256-267.

Mestecky, J., and J. R. McGhee. 1987. Immunoglobulin A (IgA): Molecular and cellular interactions involved in IgA biosynthesis and immune response. Adv. Immunol. 40:153-245.

Oddy, W. H., M. Halonen, F. D. Martinez, I. C. Lohman, D. A. Stern, M. Kurzius-Spencer, S. Guerra, and A. L. Wright. 2003. TGF- $\beta$ in human milk is associated with wheeze in infancy. J. Allergy Clin. Immunol. 112:723-728.

Ogawa, J., A. Sasahara, T. Yoshida, M. M. Sira, T. Futatani, H. Kanegane, and T. Miyawaki. 2004. Role of transforming growth factor- $\beta$ in breast milk for initiation of IgA production in newborn infants. Early Hum. Dev. 77:67-75. 
Ogundele, M. O. 2000. Techniques for the storage of human breast milk: Implications for anti-microbial functions and safety of stored milk. Eur. J. Pediatr. 159:793-797.

Oslislo, A., Z. Czuba, H. Slawska, W. Kazmierczak, and W. Król. 2007. Decreased human milk concentration of epidermal growth factor after preterm delivery of intrauterine growth-restricted newborns. J. Pediatr. Gastroenterol. Nutr. 44:464-467.

Permanyer, M., C. Castellote, C. Ramírez-Santana, C. Audí, F. J. Pérez-Cano, M. Castell, M. C. López-Sabater, and À. Franch. 2010. Maintenance of breast milk immunoglobulin A after highpressure processing. J. Dairy Sci. 93:877-883.

Picciano, M. F. 2001. Nutrient composition of human milk. Pediatr. Clin. North Am. 48:53-67.

Playford, R. J., C. E. Macdonald, and W. S. Johnson. 2000. Colostrum and milk-derived peptide growth factors for the treatment of gastrointestinal disorders. Am. J. Clin. Nutr. 72:5-14.

Reynolds, G. J., D. I. Lewis-Jones, D. M. Isherwood, H. J. Meade, B. J. Brown, and T. S. Fitzgerald. 1982. A simplified system of human milk banking. Early Hum. Dev. 7:281-292.

Romeu-Nadal, M., A. I. Castellote, and M. C. López-Sabater. 2008. Effect of cold storage on vitamins $\mathrm{C}$ and $\mathrm{E}$ and fatty acids in human milk. Food Chem. 106:65-70.
Rudloff, H. E., F. C. Schmalstieg Jr., A. A. Mushtaha, K. H. Palkowetz, S. K. Liu, and A. S. Goldman. 1992. Tumor necrosis factor- $\alpha$ in human milk. Pediatr. Res. 31:29-33.

Slutzah, M., C. N. Codipilly, D. Potak, R. M. Clark, and R. J. Schanler. 2010. Refrigerator storage of expressed human milk in the neonatal intensive care unit. J. Pediatr. 156:26-28.

Strobel, S. 2002. Oral tolerance, systemic immunoregulation, and autoimmunity. Ann. N. Y. Acad. Sci. 958:47-58.

Tacken, K. J. M., A. Vogelsang, R. A. van Lingen, J. Slootstra, B. D. Dikkeschei, and D. Van Zoeren-Grobben. 2009. Loss of triglycerides and carotenoids in human milk after processing. Arch. Dis. Child Fetal Neonatal 94:F447-F450.

Uruakpa, F. O., M. A. H. Ismond, and E. N. T. Akobundu. 2002. Colostrum and its benefits: A review. Nutr. Res. 22:755-767.

Walker, A. 2010. Breast milk as the gold standard for protective nutrients. J. Pediatr. 156:S3-S7.

Wight, N. E. 2001. Donor human milk for preterm infants. J. Perinatol. 21:249-254. 